\title{
A study of effect of Gender, school resources and Teacher-pupil ratio on achievement of Government and Private school Students at secondary stage of education.
}

\author{
Shaikh Ehteshamuddin *, Prof. (Dr.) Shaikh Azimuddin** \\ *Research Scholar Integral University Lucknow. \\ **Dean (Faculty Of Education) Integral University Lucknow.
}

\begin{abstract}
This study explored the impact of gender, school resources and teacher-pupil ratio on academic achievement of secondary school students. A convenient sample of 1567 students, 770 Government and 797 Private students from fourty schools of Aurangabad, Nanded and Parbhani districts of Maharashtra (India) was used for present study. The VIIIth grade final marks for academic Achievement scores and School assessment Scale were used for data collection, while t-test, Mean and S.D. techniques were used for statistical analysis. The results revealed that there was a significant difference between academic achievement of Government and Private secondary school students on gender and resources basis. The results of analysis showed that Government and Private secondary schools are using comparatively the same school inputs and teacher-pupil ratio. Moreover the students of Government schools had higher academic achievement in comparison to Private managed schools.
\end{abstract}

Key Words: Gender, school resources, Academic achievement, Teacher-pupil ratio

\section{Introduction:}

Education in its broadest sense may be defined as a process designed to inculcate the knowledge, skills and attitudes necessary to enable individuals to cope up effectively with their environment. Its primary purpose is to foster and promote the fullest individual self realization for all people. Achieving this goal requires understanding of commitment to the proposition that education is a primary instrument for social and economic advancement of human welfare (Verma 1990).

Education in its largest sense is any act or experience that has a formative effect on mind, character and physical ability of an individual. In its technical sense, education is a process by which society deliberately transmits its accumulated knowledge, skills and values from one generation to another. Etymologically, the word education is derived from educare (Latin) "bring up", which is related to educere "bring out", "bring forth what is within", "bring out potential" and ducere, "to lead".

The world is becoming more and more competitive. Quality of performance has become the key factor for personal progress. Parents desire that their children climb the ladder of performance to as high a level as possible. This desire for high level of achievement puts a lot of pressure on students, teachers, and school and in general the education system itself. In fact, it appears as if the whole system of education revolves around the academic achievement of students, though various other outcomes are also expected from the system. Thus a lot of time and effort of the schools are used for helping students to achieve better in their scholastic endeavors. The importance of scholastic and academic achievement has raised important questions for educational researchers. How far the different factors contribute towards academic achievement? (Ramaswamy 1990).

According to the sixth All India educational survey (NCERT-1995) in India, secondary and senior secondary levels of education have growth at an unequal pace from $25.85 \%$ to $52.11 \%$ during 1986 to 1993 . This has influenced the demands for tertiary and higher education. in present scenario secondary education should not be viewed as a mere extension of secondary education rather, it should be perceived as the preparation of adolescent as a better human resource, capable of contributing to economic, social and national development.

Education is the process of developing the capacities and potentials of the individuals as to prepare that individual to be successful in a specific society or culture. From this perspective, education is serving primarily as an individual development function. Education begins at birth and continues throughout life. It is constant and ongoing. Schooling generally begins somewhere between the ages four and six when children are gathered together for the purpose of specific guidance related to skills and competencies that society deems important. In the past, once the formal, primary and secondary schooling was completed the process was finished. However, in today's information age, adults are quite often learning in informal setting throughout their working lives and even into retirement. 
In our society academic achievement is considered as a key criterion to judge one's total potentialities and capacities. Hence academic achievement occupies a very important place in education as well as in the learning process. Academic achievement is defined by Crow and Crow (1969) as the extent to which a learner is profiting from instructions in a given area of learning. i-e achievement is reflected by the extent to which skill and knowledge has been imparted to him. Academic achievement also denotes the knowledge attained and skill developed in the school subject, usually designated by test scores. Achievement is influenced by personality, motivation, opportunities, education and training.

Whether raising school expenditure is an effective way to improve educational outcomes is a contentious issue. Hanushek (2008) argues that accumulated research says that there is currently no clear, systematic relationship between resources and students outcome, with the implication that conventional input policies are unlikely to improve achievement. However, a critique of this argument has pointed out to a number of high quality studies that suggest otherwise. Two well known examples included the paper on class size in Israel (Angrist \& Lavy, 1999) and the experimental Tennessee STAR class size reduction papers (Krueger, 1999; Krueger \& Whitmore, 2001). A difficulty with this debate is that studies with an excellent methodological design are rare and data available to researchers usually falls well short of the ideal. Thus, it is not clear how far one can use the literature to give policy advice on whether or not Government should raise the amount of money they spend on school education.

A good number of empirical studies in developed countries were conducted on school resources (Wilson Kathryn, 1996: Magdalena Mok and Marcellin, 1997: Heyneman and Loxley, 1983: Richard David, 1992: Behrman et, al 1997: etc). In India a few studied on resources at secondary stage were also conducted. (Varghese, N.V. 1993: Govinda and Varghese, 1994: Sajitha Bashir, 1994: Kingdon, 1994: Singh and Saxena, 1995: Satvir Singh, 1996) etc.

\section{OBJECTIVES:}

1. To study the academic achievement of students enrolled in Government and Private secondary schools on gender basis.

2. To study the school resources in Government and Private secondary schools.

3. To study the Teacher-pupil ratio in Government and Private secondary schools.

HYPOTHESES:

1. There is no significant difference between achievement levels of Government secondary school students on gender basis.

2. There is no significant difference between achievement levels of Private secondary school students on gender basis.

3. There is no significant difference between achievement levels of male Government and Private secondary school students.

4. There is no significant difference between achievement levels of male Government and Private secondary school students.

5. There is no significant difference between achievement levels of Female Government and Private secondary school students.

6. There is no significant difference between school resources of Government and Private secondary schools.

7. There is no significant difference between teacher-pupil ratio of Government and Private secondary schools.

\section{Research tools:}

Following tools are employed for gathering data needed for the present study.

1. The measure of academic achievement is based on the marks obtained in the VIII ${ }^{\text {th }}$ grade examination conducted by the school.

2. School Inputs Assessment Questionnaire prepared by the investigator.

\section{Methodology:}

The Research is conducted in Aurangabad, Nanded and Parbhani districts of Maharashtra state. 40 secondary schools are selected as a sample with stratified random sampling technique.20 schools were Government and 20 schools were private. Out of the sample of 1567 students 770 students were Government secondary school students and 797 students from private secondary schools. Academic achievement score of all students of IXth class is collected by the final marks of VIIIth class from their school register records under the supervision of respective head masters of those schools. School inputs and teacher-pupil ratio scores is obtained by school inputs assessment questionnaire. For the analysis of data researcher used descriptive and 
inferential statistics. Researcher used central tendency (mean), standard deviation (SD), t-test for significant difference between two means.

\section{Findings and conclusion:}

\subsection{Comparison of academic achievement between male \& female students of Government secondary} schools:

The total numbers of male and female Government secondary school students were 386 and 384 respectively as indicated by table number 4.1. out of total 100 scores the mean academic achievement score of male Government secondary school student is 60.44 and standard deviation $(\mathrm{SD}=7.62)$ and in case of female Government secondary school students the mean academic achievement score is 59.00 and standard deviation $(\mathrm{SD}=6.61)$ respectively; the calculated $\mathrm{t}$-value is $2.79 \mathrm{at} \mathrm{df}=768$; which is significant at 0.05 level of significance. It shows that there is a significant difference between the academic achievement of male and female Government secondary school students both are performing differently in their respective schools thus the second hypothesis stating that "Government secondary school students do not differ in academic achievement on gender basis". Is rejected at 0.05 level of significance. The graphical representation of mean academic achievement scores of Male and Female Government secondary school students is given in fig. 4.1.

\section{Type of School(Govt.)} 6.61

N Mean S.D. df " $t$ "-ValueMale students $38660.447 .62768 \quad 2.79 * *$ Female students 38459.00

$$
\text { **significant }
$$

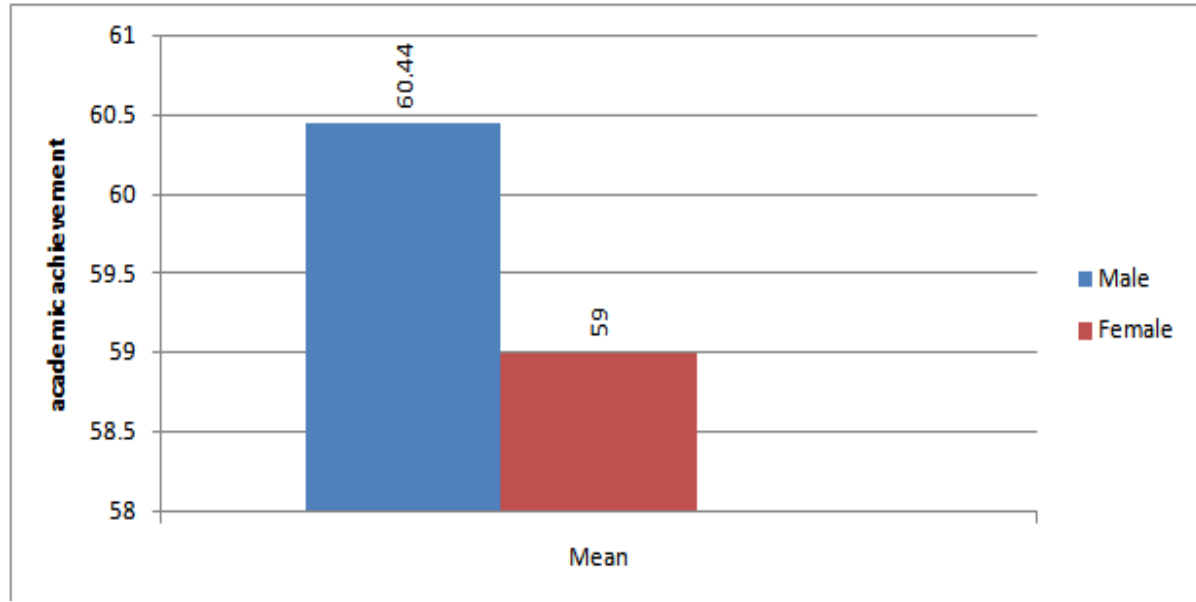

Fig.4.1 Graph of Academic achievement of Male and Female Government secondary school students.

4.2. Comparison of academic achievement between male \& female students of Private secondary schools:

The total numbers of male and female Private secondary school students were 384 and 413 respectively as indicated by table number 4.2. out of total 100 scores the mean academic achievement score of male Private secondary school student is 59.45 and standard deviation $(\mathrm{SD}=7.49)$ and in case of female Private secondary school students the mean academic achievement score is 58.86 and standard deviation $(\mathrm{SD}=6.68)$ respectively; the calculated t-value is 1.18 ; with $795 \mathrm{df}$. Which is not significant at 0.05 level. The result shows that there is no significant difference between academic achievement of male and female students of Private schools. Both are equally performing in Private schools on academic achievement basis. Thus the hypothesis "Private secondary school students do not differ in academic achievement on gender basis." is accepted at 0.05 level of confidence". Graphical representation in figure 4.2.

Type of School(Pvt) N Mean S.D. df “ $t$ "-ValueMale students38459.457.49 795

$1.18 *$ Female students41358.866.68

*Not significant 


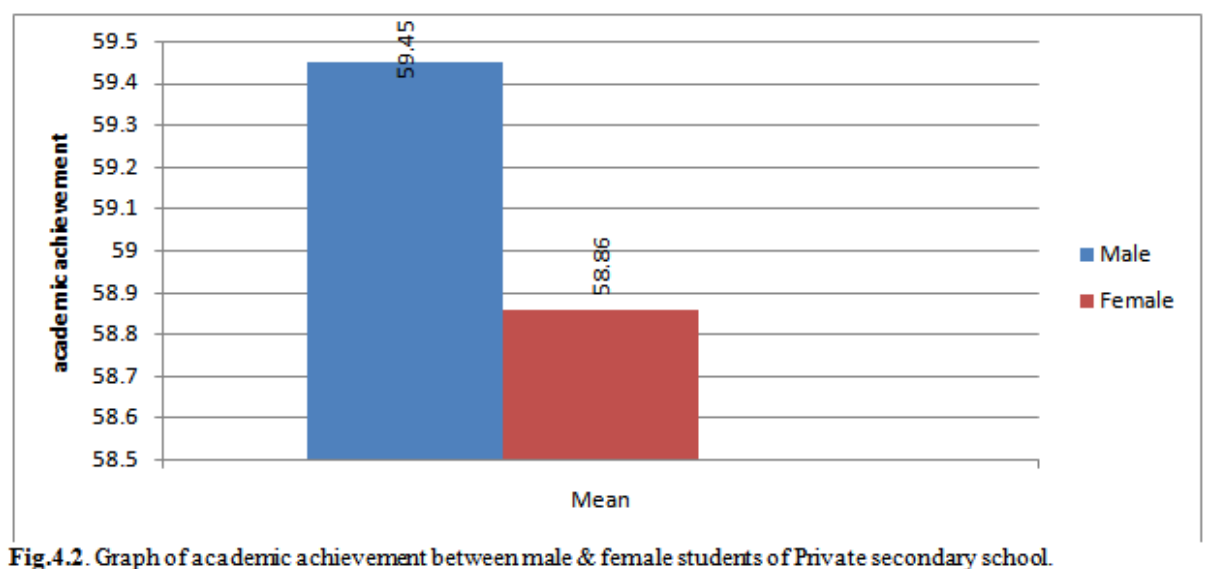

4.3. Comparison of academic achievement between male students of Government \& Private secondary Schools.

The total numbers of male Government secondary school students were 386 and private male students were 384 respectively as indicated by table number 4.3 . out of total 100 scores the mean academic achievement score of male government secondary school student is 60.44 and standard deviation $(\mathrm{SD}=7.62)$ and in case of male Private secondary school students the mean academic achievement score is 59.45 and standard deviation $(\mathrm{SD}=7.49)$ respectively; the calculated t-value is 1.81 ; with $768 \mathrm{df}$. Which is not significant at 0.05 level. The result shows that there is no significant difference between academic achievement of male students of government and Private schools. Both are equally performing in respective schools on academic achievement basis. Thus the hypothesis "There is no significant difference between academic achievement of male students of Government and Private secondary school." is accepted at 0.05 level of confidence". Graphical representation in figure 4.3.

Type of School NMean S.D. df" $t$ "-ValueMale(Govt.) 38660.447 .62

$7681.81 *$ Male (Pvt) 38459.457 .49

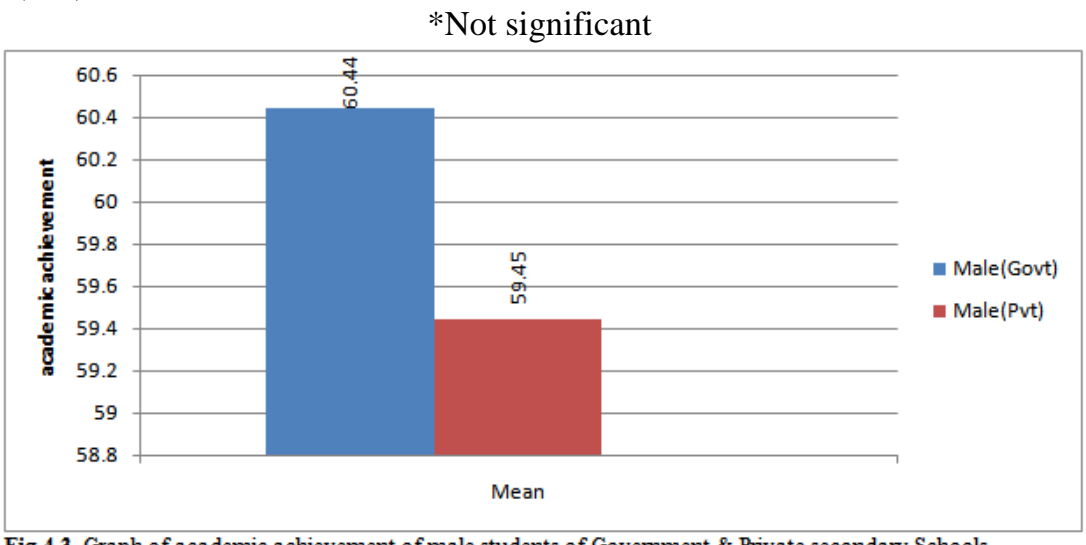

Fig.4.3. Graph of academic achievement of male students of Govemment \& Private secondary Schools.

4.4. Comparison of academic achievement between female students of Government \& Private secondary Schools.

The total numbers of Government and Private female secondary school students were 384 and 413 respectively as indicated by table number 4.4. out of total 100 scores the mean academic achievement score of female government secondary school student is 59.00 and standard deviation $(\mathrm{SD}=6.61)$ and in case of female Private secondary school students the mean academic achievement score is 58.86 and standard deviation ( $\mathrm{SD}=6.68)$ respectively; the calculated $\mathrm{t}$-value is 0.30 ; with $795 \mathrm{df}$. Which is not significant at 0.05 level. The result shows that there is no significant difference between academic achievement of female students of Government and Private secondary schools. Both are equally performing in their schools on academic achievement basis. Thus the hypothesis "There is no significant difference between academic achievement of female students of Government and Private secondary School." is accepted at 0.05 level of confidence". Graphical representation in figure 4.4 . 
Type of School N Mean S.D. df “ t "-ValueFemale(Govt.) $38459.006 .61795 \quad 0.30 *$ Female (Pvt) 41358.866 .68

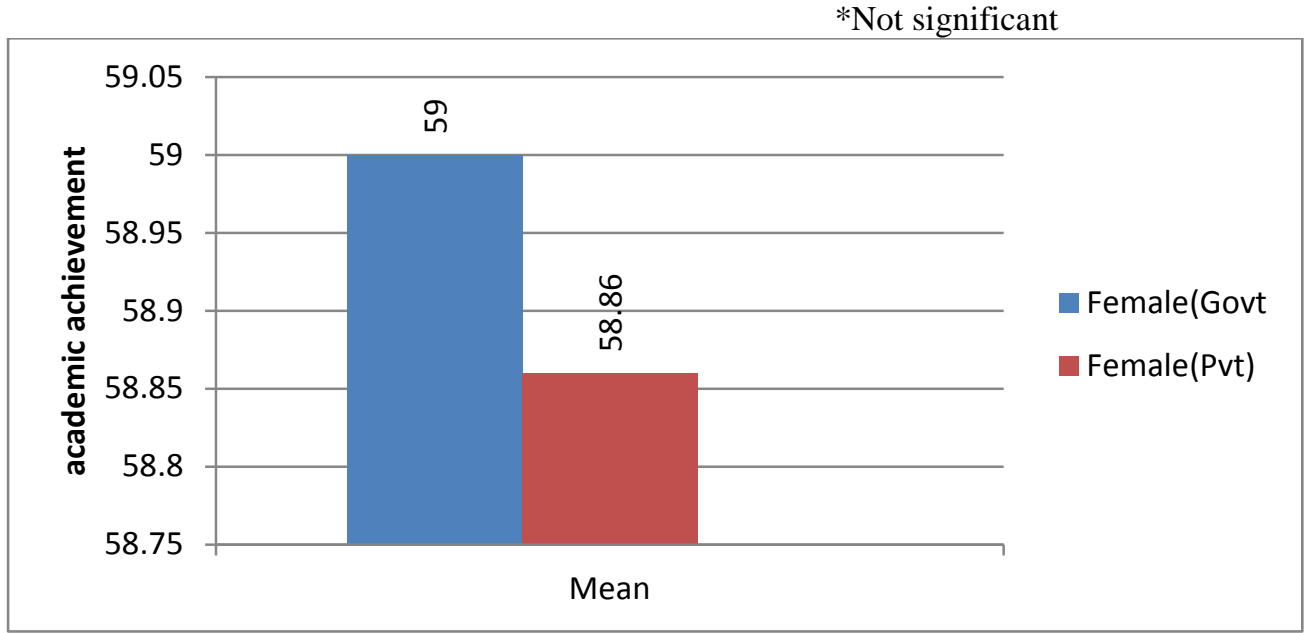

Fig. 4.4. Graph of academic achievement between female students of Government \& Private secondary Schools.

\subsection{Comparison of School resources in Government and Private secondary Schools.}

In total 40 schools 20 Government secondary schools and 20 Private schools were selected for the school input study. The calculated mean school input score of Government secondary schools was 37.80 and standard deviation $(S . D=12.94)$ and the mean school input score of Private secondary schools was 42.75 and standard deviation $(S . D=13.85)$ at $38 \mathrm{df}$ respectively. The calculated t-value is 1.16 at 0.05 level of significance which is not significant. It means that there is no significant difference between school inputs of Government and Private secondary schools both operates with comparatively insignificant school inputs thus the hypothesis stating "There is no significant difference between school inputs of government and private secondary school" is accepted at 0.05 level of significance. Graphical representation in figure 4.5.

School Resources Mean S.D df “ t "-Value Government Schools 207.8012 .94381 .16 * Private Schools 20 42.7513 .85

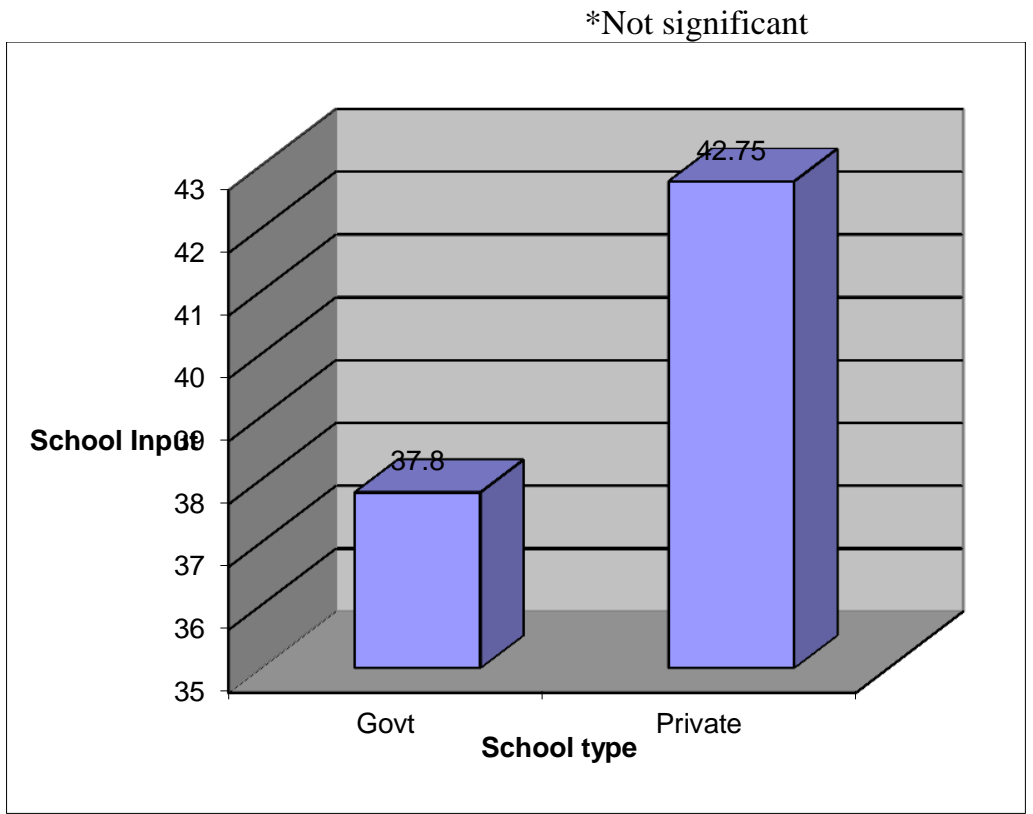

Fig.4.5 . Graph of School inputs of Government \& Private secondary schools.

\subsection{Comparison of Teacher-Pupil Ratio in Government \& Private secondary schools.}

In case of Teacher-pupil ratio of 40 secondary schools the calculated mean score of teacher-pupil ratio of 20 Government secondary school was 5.80 and standard deviation ( $\mathrm{S} . \mathrm{D}=1.32)$. In 20 Private secondary schools the obtained mean score of teacher-pupil ratio was 5.10 and standard deviation $(\mathrm{S} . \mathrm{D}=1.80)$ at $38 \mathrm{df}$ respectively. Calculated t-value is 1.76 which is not significant at 0.05 level of confidence. It clearly indicates 
that Government and Private secondary schools operates with insignificant teacher-pupil ratio there is no significant difference in both types of school thus the hypothesis "There is no significant difference between teacher-pupil ratio of government and private secondary schools" is accepted at 0.05 level of significance. Graphical representation in figure 4.6.

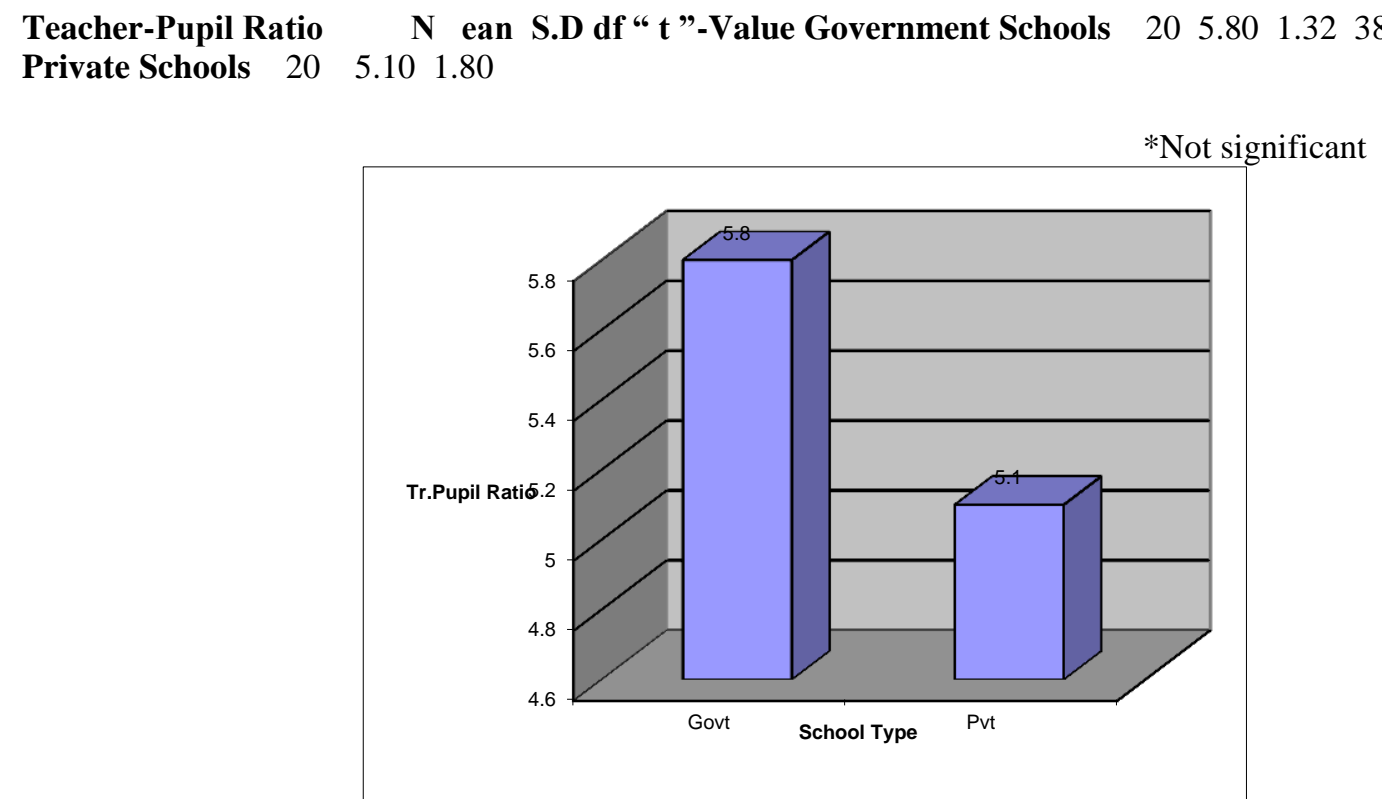

Fig. 4.6 . Graph of Teacher-Pupil ratio in Government \& Private secondary schools.

\section{Discussion:}

The purpose of the present study was to determine the effects of Gender, school resources and teacher-pupil ratio on the academic achievement of Government and Private secondary school students. These variables were chosen for analysis because they are manipulable variables that have been identified as important influences on the academic achievement of students in previous researches. Data from 40 secondary school sample was analyzed. T-test used for obtaining significant difference of means of two samples and F-test is used for the purpose of determining significant difference between many means. To determine the effect of these variables on academic achievement of secondary school students while controlling for other relevant background influences.

The results of analysis of data shows that gender differences, school inputs, school resources, teacher's qualification, school infrastructure, teacher-pupil ratio in schools all had significant effect on academic achievement scores of Government and Private secondary school students.

The finding of this study is supported by Dhar et. al (2011) who stated that attitude of teachers towards teaching and the extent of use of their skills, expertise and abilities in teaching have greater effect on students academic achievement. Gleww et. al (2011), Paulo et. al (2008) concluded that school resources play a vital role in upgrading the academic outcomes of secondary school and school resources have positive effect on students academic achievement.

Holmlund et. al (2008) also reported that raising school expenditure improves educational outcomes and general rise in school expenditure has a consistently positive and significant effect on educational outcomes of school.

Doane B. T (2008) found that the school facilities affect the student's academic achievement significantly. Whereas in words of Barbra Hotchkiss "learning in historic school facility provide students with a unique educational experience that cannot be replicated in a modern facility".

In words of fabunmi et. al (2007) class size, student classroom space and class utilization when taken together or separately have significant effect on academic achievement of secondary school students.

Kathryn \& margerete (2003) found that teacher-pupil ratio and resource utilization leads to different resource effect and there is significant relationship between school inputs and academic achievement. Many researches shown that school inputs and school expenditure affect academic achievement of secondary school students. School inputs available in Private school has much effect on academic achievement. School expenditure has a vice-versa effect on student's performance. Raise in school expenditure positively affects the academic performance of secondary school students, Mark Schneider (2002), Harter (1999), Beharman et. al (1997), Psacheropoules et,al (1997), Middleton Roper David (1996). 
Duraisamy (1999) found that school cost and some indicators of inputs in public and Private schools have greater influence on student's academic achievement. It also concluded that teachers, school input cost, teacher-pupil ratio has positive effect on academic achievement of students, and student from Private schools done better academically than public school students.

From all these we can conclude that the school inputs, school resources, cost and expenditure has positive effect on academic performance of secondary school student. Students of schools equipped with better school inputs and resources perform academically better than Government school student. Beside studies conducted by Harter 1999, David Richard 1992, white 1992, Magdelena Mek et, al, 1995, singh satvir 1996. Came to the conclusion that School Inputs (school infrastructure, condition \& facilities) largely enhance academic achievement.

From all these we can conclude that the school inputs, school resources, cost and expenditure has positive effect on academic performance of secondary school student. Students of schools equipped with better school inputs and resources perform academically better than Government school student.Beside studies conducted by Harter 1999, David Richard 1992, white 1992, Magdelena Mek et, al, 1995, singh satvir 1996. Came to the conclusion that School Inputs (school infrastructure, condition \& facilities) largely enhance academic achievement.

\section{Educational implication:}

This study shows that school inputs and school resources has a significant influence on academic achievement of students, it is very helpful for parents, school teachers, principals and policy makers. It will assist parents where to admit their children as well as teachers and principal understand the difference of school inputs and will care about it. Policy makers with the help of this study can form better teaching learning process. It will help school authorities in academic achievement enhancement and ways to promote teaching learning process among students. Education system should provide the platform to each student where school resources and teacher-pupil ratio do not affect the academic achievement of student in any case.

\section{References:}

[1] Angrist, J. and V. Lavy (1999), Using Maimonides" rule to estimate the effect of class size on scholastic achievement, Quarterly Journal of Economics, 114, 533-75. Department for Education and Skills/HM Treasury (2005), Child Poverty: Fair Funding for Schools. London: Department for Education and Skills/Treasury.

[2] Bashir, \& Sajitha. (1994). Achievement Performance at the Primary Level in Public and Private Schools of Tamil Nadu: Preliminary Analysis Using Ordinary Least Squares, New Delhi: Indian Educational Review. Vol. 29, National Council of Educational Research and Training.

[3] Behrman, et al. (1997). School Quality and Cognitive Achievement Production: A Case Study of Rural Pakistan, Great Britain: Economics of Education Review Vol. 16, No. 2, Elsevier Science Ltd.

[4] Benjamin Thomas Doane, (2008). The relationship between school facilities \& academic achievement, dept. of teacher Ed. Ohio University, M.Ed 2008.

[5] Coleman, j. S., E. Q. Campbell, C. J. Hobson, J. Mc Portland, A. M. Mood, F. D. Winfield, and R. L. York. (1966). Equality of Educational Opportunity. Washington, DC: U.S. Government Printing Office.

[6] Crow, L.D. and Crow. (1969). Adolescent development and adjustment, Mc Grow - Hill Book Company, United States.

[7] Dahar, M.A., Dahar, R.A., Iqbal, M.Z. \& Faize, F.A., (2010), Impact of Per Pupil Expenditures on the Academic Achievement of Students at the Secondary Stage in Pakistan, International Journal of Finance and Economics, Issue 52 pp. 124-135, ISSN: 1450-2887.

[8] David Richard. (1992). The Relationship between Financial Expenditure and Student Achievement in Selected Texes School Districts, Swetnam East Texes State University.

[9] Fabunmi, M. (1997). Differential Allocation of Educational Resource and Secondary Schools Academic Performance in Edo State (1989-1994). Unpublished Ph.D Thesis, Ibadan: University of Ibadan.

[10] Fabunmi, M. and A. Okore. (2000). "Analysis of the Relationship Between Average Class size and Secondary School Academic Performance.” Africa Journal of Educational Planning Policy Studies, 1(2): 107-115.

[11] Fuller and Clarke. (1994)."Raising School Effects While Ignoring Culture? Local Conditions and the Influence of Classroom Tools, Rules and Pedagogy." Review of Educational Research, 64(1), pp. 119-157.

[12] Glewwe, Paul, Michael Kremer, Sylvie Moulin and Eric Zitzewitz. (2000b). "Retrospective vs. Prospective Analyses of School Inputs: The Case of Flip Charts in Kenya". NBER Working Paper No. 8018. Cambridge, MA

[13] Hanushek, Eric A. (1998). The evidence on class size. Public Testimony, Washington, DC

[14] Hanushek, Eric. (1995). "Interpreting Recent Research on Schooling in Developing Countries," World Bank Research Observer, 10(2): 227-46.

[15] Hanushek, Erik A. (1997). Assessing the Effects of School Resources on Student Performance: An Update, Educational Evaluation and Policy Analysis 19(2): 141-164.

[16] Harter .A. Elizabeth. (1999) How Educational Expenditures Relate to Student Achievement: Insights From Taxes Elementary School, Reston: Journal of Educational Finance, Vol. 24, No. 3, Association of School Business Officials International, North Shore Drive.

[17] Helena Holmlund, Sandra McNally,\& Martina Viarengo (2008).Does Money Matter for Schools?, IZA Germany, Discussion paper series. , London School of Economic Discussion Paper No. 3769October 2008

[18] Heyneman, S. P., \& Loxley, W. (1983). The effect of primary school quality on academic achievement across 29 high and low income countries. American Journal of Sociology, 88(6), 11-62.

[19] Howley, C. B. (1994). The academic effectiveness of small scale schooling (an update). ERIC Digest. Charleston.

[20] Jamuar. (1974). Study habits of college students, Allahabad, Indian international publication. Page 126. 
[21] Kathryn Sue. (1996).The Determinants of Education Achievement: A Structural Model of the Effects of Family, Neighbourhood and School Quality, Madison: The University of Wisconsin.

[22] Kingdon, G.G. (1996). Private Schooling in India: Size, Nature and Equity-Effects, Mumbai: Economic and Political Weekly, Vol 31, No.51, Hitkari House, 284, Shaheed Bhagat Singh Road.

[23] Krueger, A., and D. Whitmore (2001), The Effect of Attending a Small Class in the Early Grades on College-Test Taking and Middle School Test Results: Evidence from Project Star, Economic Journal 111: 1-28.

[24] Krueger, A.B., \& Whitmore, D.M. (2002). Would smaller classes help close the black white achievement gap? In J.E. Chubb \& T. Loveless (Eds.), Bridging the achievement gap (11-46). Washington, DC: Brookings Institution Press.

[25] Magdalena Mok, Marcellin. (1997). Catholic Schools: A Longitudinal Study of Year 12 Students in Catholic Schools 1972-19821990-1997. Sydney: Catholic Education Commission, NSW.

[26] Mark Schneider (2002), Do School Facilities Affect Academic Outcomes? National clearing house for educational facilities.

[27] Paulo A. Meyer M. Nascimento , (2008)School Resources and Student Achievement: Worldwide Findings and Methodological Issue Bahia State Department of Education (Bahia, Brazil) Educate Special Issue, pp 19-30

[28] Psacharopoulos, George. 1994. Returns to Investment in Education: A Global Update. World Development 22 (9): $1325-43$.

[29] Singh Satvir. (1996). Determinants of Learner Achievement at Primary Stage, New Delhi: Indian Education Review, Vol. 31, National Council of Educational Research and Training.

[30] Singh, and Saxena. (1995). Achievement Difference and School Effects, New Delhi: Indian Education Review, Vol. 31, No.1, National Council of Educational Research and Training.

[31] Tiwari S, Bansal I. (1994). A study of self-concept of high and low achieving adolescent girls. Indian Psychol. Rev., 43: 21-25.

[32] Varghese, N.V. (1993). "Private Schools in India: Presumptions and Previsions," in RP Singh edited Private Initiatives and Public Policy in Education.

[33] Verma and Saxena, P.C. and Mishra, U.(1990). Socio-Economic status Index. Agra:”

[34] White F.John.(1992). Private School Verses Public School Achievement: Are These Findings that Should Affect Educational Choice Debate? Great Britain: Economics of Education Review, Volume 11, No.4, Elsevier Science Ltd. 